\title{
Effect of antibodies to double stranded DNA, purified from serum samples of patients with active systemic lupus erythematosus, on the glomerular mesangial cells
}

\author{
Chang-Youh Tsai, Tsai-Hung Wu, Kuang-Hui Sun, Chia-Li Yu
}

\begin{abstract}
Polyclonal antibodies to double stranded DNA (dsDNA) purified from pooled serum samples of patients with systemic lupus erythematosus (SLE) exerted cytotoxic effects on cultured rat mesangial cells. At concentrations from 5 to $150 \mathrm{IU} / \mathrm{ml}$, antibodies to dsDNA inhibited the incorporation of thymidine labelled with ${ }^{3} \mathrm{H}$ into rat mesangial cells in a dose response manner after three days of culture. In contrast, normal human IgG $(1 \mathrm{mg} / \mathrm{ml})$, heat aggregated human IgG (1 mg/ml), $\boldsymbol{N}$-formyl-methionyl-leucyl-phenylalanine $\left(1 \times 10^{-7} \mathrm{~mol} / \mathrm{l}\right)$, tumour necrosis factor $\alpha(16(\mathrm{U} / \mathrm{ml})$, lipopolysaccharides $(1 \mu \mathrm{g} / \mathrm{ml})$, 4 $\beta$-phorbol-12 $\beta$-myristate-13 $\alpha$-acetate (PMA) $(20 \mathrm{ng} / \mathrm{ml})$, interleukin $1 \beta(10 \mathrm{U} / \mathrm{ml})$, and $20 \%$ $\mathrm{v} / \mathrm{v}$ phytohaemagglutinin stimulated mononuclear cell supernatant showed no significant effect on these cells. Anticardiolipin antibody, another autoantibody purified from the serum of patients with SLE, also inhibited the proliferation of rat mesangial cells but to a lesser extent.
\end{abstract}

In the presence of antibodies to dsDNA (100 IU/ml), the mesangial cells became spherical and clustered together, which was very different from the original stellate appearance. These autoantibodies also depolarised the membrane potential of mesangial cells. Antibodies to dsDNA decreased the syntheses of prostaglandin $E_{2}$, 6-keto-prostaglandin $F_{1 \alpha}$ and thromboxane $B_{2}$ by mesangial cells. In an in vivo study, the antibodies to dsDNA showed a strong affinity for the glomeruli when intravenously injected into rats. These results suggest that the nephrotropic antibodies to dsDNA can directly damage the glomerular mesangial cells in addition to the formation of immune complexes with DNA which may cause kidney inflammation and tissue destruction.

Lupus nephritis has long been regarded as a prototype of immune complex mediated disease. In active proliferative lupus nephritis, the glomeruli show irregular proliferative, exudative, and often necrotising and sclerosing changes. Using monoclonal antibodies to surface markers, the glomerular hypercellularity in humans and experimental animals has been shown to be composed of the invading mononuclear cells and macrophages rather than the proliferation of mesangial cells. ${ }^{1-4}$ Clinically, the titres of the autoantibodies to double stranded DNA (dsDNA) are closely related to the activity of the renal inflammation. Deposition of the immune complexes between DNA and antibodies to DNA in kidneys has been considered to elucidate the inflammatory reaction in lupus nephritis. ${ }^{56}$ However, Edberg et $a l^{7}$ found that the complexes between DNA and antibodies to DNA intravenously injected into experimental animals were rapidly cleared by the reticuloendothelial system and hardly had any opportunity to deposit onto the renal glomeruli. Chetrit $e t a l^{8}$ reported that antibodies to DNA rather than complexes between DNA and antibodies to DNA had strong affinity for the kidney tissue. Raz et al found that monoclonal mouse antibody to DNA bound directly to renal antigens and increased the excretion of albumin in isolated perfused rat kidney when directly infused through the renal artery. Furthermore, many studies ${ }^{10-14}$ suggest that the pathogenic mechanism of antibodies to dsDNA in vivo is probably through the cross reactivity with molecules other than DNA. These cross reactive molecules include heparan sulphate, chondroitin sulphate, vimentin, phospholipids and certain cell surface proteins. Accordingly, it is speculated that antibodies to dsDNA may directly bind to the glomerular cells and adversely affect the function of the kidney. In this study, antibodies to dsDNA were purified from pooled serum samples of patients with active systemic lupus erythematosus (SLE) and their effects on the proliferation and functions of rat mesangial cells were investigated.

\section{Materials and methods}

REAGENTS

4 $\beta$-Phorbol-12 $\beta$-myristate-13 $\alpha$-acetate (PMA), lipopolysaccharide (Escherichia coli serotype 0128:B12), $\quad N$-formyl-methionyl-leucyl-phenylalanine (fMLP) and human IgG were obtained from Sigma Chemical (St. Louis, MO, USA). Tumour necrosis factor $\alpha$ and interleukin $1 \beta$ were purchased from Janssen Biochimica (Turnhoutseweg, Belgium). Aggregated human IgG was prepared by heating human IgG at $63^{\circ} \mathrm{C}$ for 30 minutes. The large precipitates were removed by Millipore filtration $(0.45 \mu \mathrm{m})$ and stored at $-20^{\circ} \mathrm{C}$ until use.

PURIFICATION OF ANTIBODIES TO dSDNA FROM POOLED SERUM SAMPLES OF PATIENTS

WITH ACTIVE SLE

The purification of antibodies to dsDNA followed the method described by Gilliam $e t a l^{15}$ with some modifications. ${ }^{16}$ The protein concentration of the antibodies was adjusted to 0.5 
$\mathrm{mg} / \mathrm{ml}$, determind by absorbance at $280 \mathrm{~nm}$, using human IgG as reference. The DNA binding activity of the purified antibodies was measured by an enzyme linked immunosorbent assay (ELISA) kit (Sigma Chemical).

PURIFICATION OF ANTICARDIOLIPIN ANTIBODIES FROM POOLED SERUM SAMPLES OF PATIENTS WITH ACTIVE SLE

The purification procedures followed the method of Harris et $a^{17}$ with modifications. ${ }^{18}$ The purity of these anticardiolipin antibodies was checked by $10 \%$ sodium dodecyl sulphatepolyacrylamide gel electrophoresis. The cardiolipin binding capacity was measured by the ELISA kit and the protein concentration by a Bio-Rad protein assay kit (Bio-Rad Laboratories, Richmond, CA, USA).

\section{ISOLATION AND CULTURE OF THE RAT} MESANGIAL CELLS

We followed the method described by Striker and Striker ${ }^{19}$ with some modifications. Briefly, male Sprague-Dawley rats weighing 150-200 g were killed. Their kidneys were removed and the cortex was separated from the medulla. The cortical tissue was then minced and sequentially passed through stainless steel sieves $(400,200$, and $75 \mu \mathrm{m})$. The resulting glomerular suspension was washed several times with sterile phosphate buffered saline followed by incubation with 750 $\mathrm{U} / \mathrm{ml}$ of collagenase at $37^{\circ} \mathrm{C}$ for 30 minutes. There was less than $3 \%$ contamination with tubular cells. The suspension was plated in 75 $\mathrm{cm}^{2}$ plastic flasks (Costar, Cambridge, MA, USA) with $12 \mathrm{ml}$ of RPMI 1640 medium supplemented with regular insulin $(0.66 \mathrm{U} / \mathrm{ml})$, penicillin $(100 \mathrm{U} / \mathrm{ml})$, streptomycin $(100$ $\mu \mathrm{g} / \mathrm{ml})$, and $20 \%$ heat inactivated fetal bovine serum (culture medium). They were kept in $95 \%$ air $/ 5 \%$ carbon dioxide, in a humidified incubator at $37^{\circ} \mathrm{C}$.

A total of $30-40 \%$ of the glomeruli attached to the bottom of the flask and the initial epithelial cells were replaced by mesangial cells after 10 days of culture. These cells became confluent after 15-20 days in culture, at which time subcultures were performed by detaching the cells with calcium and magnesium-free phosphate buffered saline containing $0 \cdot 125 \%$ trypsin and $1 \mathrm{mmol} / \mathrm{l}$ EDTA (pH 7·2). Generally, mesangial cells reached confluency after 7-10 days of culture. Cells were fed every 72 hours. All experiments were performed using cells between passages 2 and 10 .

The mesangial cells were identified by the following criteria: $(a)$ the cells were spindle shaped or stellate rather than polygonal in appearance with prominent cytoplasmic fibrillar structures under phase contrast microscopic observation; $(b)$ the cells contained myosin in the cytoplasm as confirmed by immunoperoxidase staining; $(c)$ the cells were resistant to the aminonucleoside of puromycin present in the culture medium; and $(d)$ the cytoplasm was devoid of factor VIII as confirmed by immunofluorescent antibody stain.
MEASUREMENT OF THE INCORPORATION OF ${ }^{3}$ H-THYMIDINE IN CULTURED RAT MESANGIAL CELLS

One hundred microlitres of mesangial cells $\left(3 \times 10^{5} / \mathrm{ml}\right), 0.06 \mathrm{ml}$ of culture medium, and $0.04 \mathrm{ml}$ of the individual reagents in various concentrations were added into a microtitre well. The mixture was incubated overnight at $37^{\circ} \mathrm{C}$ in an atmosphere of $95 \%$ air $/ 5 \%$ carbon dioxide before adding $18.5 \mathrm{kBq}$ [methyl] ${ }^{3} \mathrm{H}$ thymidine (specific activity $247.9 \mathrm{kBq} / \mathrm{mmol}$, NEN Products, Boston, MA, USA). After incubation for an additional 48 hours, the supernatant was carefully removed and the cells were gently washed several times with warm $10 \%$ fetal bovine serum/RPMI. The monolayer was then harvested using $0 \cdot 125 \%$ trypsin/ $1 \mathrm{mmol} / \mathrm{l}$ EDTA in phosphate buffered saline. The radioactivity of the mesangial cells was measured by a betacounter. In a similar experiment, the cells and antibodies to dsDNA (100 $\mathrm{IU} / \mathrm{ml}$ ) were mixed and incubated for three days without the addition of ${ }^{3} \mathrm{H}$-thymidine. These cells were fixed with $10 \%$ formalin for 10 minutes and stained with Wright's method for morphological study.

DETERMINATION OF PROSTAGLANDIN $E_{2}$, PROSTACYCLIN (6-KETO-PGF ${ }_{1 \alpha}$ ), AND THROMBOXANE $B_{2}$ IN THE CULTURED SUPERNATANT OF MESANGIAL CELLS Mesangial cells $\left(3 \times 10^{4}\right.$ per well) were cultured in serum free medium (Gibco, Grand Island, NY, USA) supplemented with $6.5 \mathrm{ng} / \mathrm{ml}$ of epidermal growth factor (Sigma) in the presence of antibodies to dsDNA (100 IU/ml) or human IgG $(1 \mathrm{mg} / \mathrm{ml})$ for three days. The cell free culture supernatants were further purified by separation on a Sep-Pak cartridge before assay. The concentrations of prostaglandin $\mathrm{E}_{2}$, 6-ketoprostaglandin $F_{1 \alpha}$, and thromboxane $B_{2}$ in various culture supernatants were determined by commercially available EIA kits (Cayman Chemical, Ann Arbor, MI, USA). The detailed procedures are described in the respective instruction booklets.

DETERMINATION OF THE CHANGE IN MEMBRANE POTENTIAL OF THE INDIVIDUAL MESANGIAL CELLS IN THE PRESENCE OF ANTIBODIES TO dsDNA The membrane potential was measured by the method of Shapiro et al. ${ }^{20}$ The indicator dye used was 3,3'-dihexyloxacarbocyanine iodide (Eastman Kodak, Rochester, NY, USA). The mesangial cells $\left(1 \times 10^{6} / \mathrm{ml}\right)$ and antibodies to dsDNA (100 IU/ml) were incubated in plastic Petri dishes for three days before harvesting. The floating and attached cells were collected separately. The membrane potentials of these cells were estimated by EPICS C flow cytometry (Coulter Electronics, Hialeah, Miami, FL, USA) with excitation at $488 \mathrm{~nm}$.

INFUSION OF ANTIBODIES TO dsDNA INTO RATS Male Sprague-Dawley rats $(200-250 \mathrm{~g})$ were selected for infusion with antibody. Eight hundred microlitres of antibodies to dsDNA 
(400 IU/ml) or human IgG $(5 \mathrm{mg} / \mathrm{ml})$ were injected intravenously through the tail veins under pentothal anaesthesia. The rats were killed six hours after injection. The kidneys were removed and cut into $0.5 \times 0.5 \times 0.5 \mathrm{~cm}$ blocks. Some blocks were immediately frozen and sliced into $5 \mu \mathrm{m}$ thick slices for immunoperoxidase staining and the others were fixed with $10 \%$ formalin for haematoxylin-eosin staining. For the immunoperoxidase stain, the samples were fixed in acetone for 10 minutes followed by three washes in phosphate buffered saline. The endogenous peroxidase activity was inhibited by preincubating sections with methanol/hydrogen peroxide $(0.2 \mathrm{ml}$ hydrogen peroxide in $11.8 \mathrm{ml}$ methanol) for 10 minutes. They were then incubated with horseradish peroxidase conjugated rabbit antibodies to human IgG (1:50 dilution) for $\mathbf{4 5}$ minutes. After three washes in phosphate buffered saline (five to ten minutes each), the specimens were incubated with substrate solution, which was prepared just before use by dissolving $1 \mathrm{mg}$ $3,3^{\prime}$-diaminobenzidine in $10 \mathrm{ml}$ TRIS-HCl buffer $(\mathrm{pH} 7)$ and $0.1 \mathrm{ml} 1 \%(\mathrm{v} / \mathrm{v})$ hydrogen peroxide. After incubation for 10 minutes at room temperature, the sections were washed once in phosphate buffered saline for six minutes and counter stained with Meyer's haematoxylin for two minutes. The counter stained sections were washed again in running tap water. The specimens were dehydrated by incubating for three minutes in $70 \%(\mathrm{v} / \mathrm{v})$ ethanol and then twice in absolute alcohol. Finally, the sections were dipped three times in xylene and mounted with DPX mountant for microscopic observation. The formalin fixed specimens were prepared for haematoxylin and eosin staining by standard procedures.

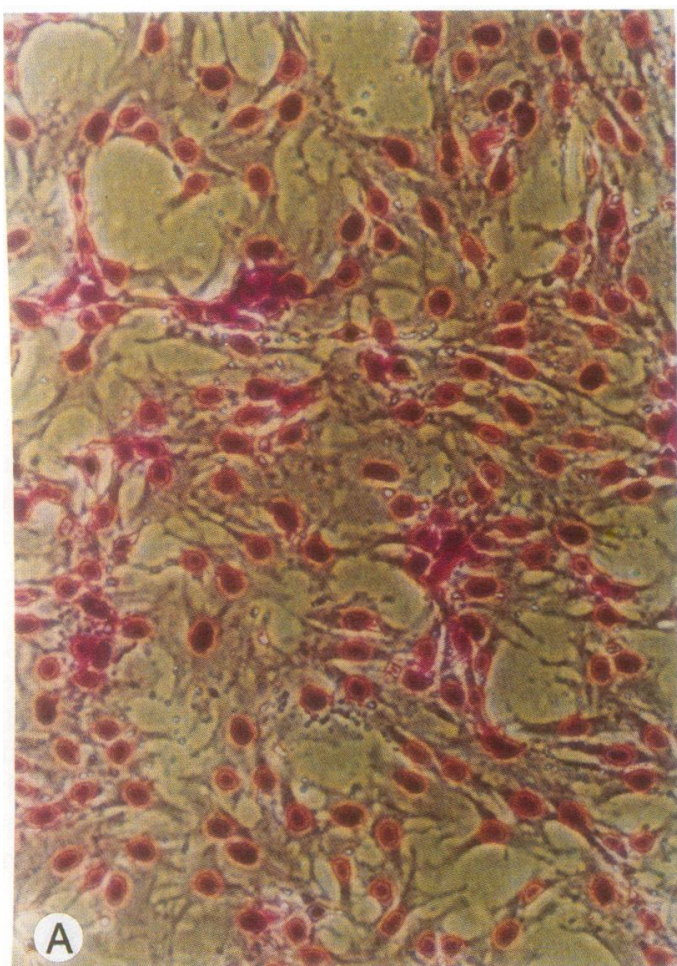

STATISTICAL ANALYSIS

The results are given as mean (standard deviation (SD)). The statistical significance was analysed by the non-parametric Wilcoxon signed rank test.

\section{Results}

EFFECT OF ANTIBODIES TO dsDNA ON THE

GROWTH OF MESANGIAL CELLS

The proliferation of mesangial cells was evaluated by ${ }^{3} \mathrm{H}$-thymidine incorporation into the cells. Table 1 shows that the percentage incorporation of control mesangial cells cultured with 100 $\mathrm{IU} / \mathrm{ml}$ of antibodies to dsDNA $(40 \cdot 60(9 \cdot 27) \%)$ was significantly lower than that of the cells cultured with $1 \mathrm{mg} / \mathrm{ml}$ of normal human $\mathrm{IgG}$ $(118 \cdot 54(8 \cdot 50) \%)$. This inhibition of proliferation of mesangial cells by antibodies to dsDNA was dose dependent in the range $5-150 \mathrm{IU} / \mathrm{ml}$. A high concentrations $(100 \mathrm{IU} / \mathrm{ml})$ of antibodies to dsDNA the cells underwent conspicuous morphological changes (fig 1). They became

Table 1 Effect of human IgG, heat aggregated human IgG (Agg.IgG), anticardiolipin and anti-dsDNA antibodies on the ${ }^{3} \mathrm{H}$-thymidine incorporation of rat mesangial cells $\left(\mathrm{MC} ; 3 \times 10^{4}\right.$ cells per well) after three days of culture

\begin{tabular}{|c|c|c|}
\hline Medium & $\begin{array}{l}\text { Percentage of } \\
\text { control } \\
\text { (mean }(S D))\end{array}$ & $p$ Valuet \\
\hline $\begin{array}{l}\mathrm{MC}+\text { medium } \\
\mathrm{MC}+\mathrm{IgG}(1 \mathrm{mg} / \mathrm{ml}) \\
\mathrm{MC}+\text { Agg.IgG }(1 \mathrm{mg} / \mathrm{ml}) \\
\mathrm{MC}+\text { anti-dsDNA }(100 \mathrm{IU} / \mathrm{ml}) \\
\mathrm{MC}+\text { anticardiolipin }(90 \mu \mathrm{g} / \mathrm{ml})\end{array}$ & $\begin{array}{l}100 \\
118 \cdot 54(8 \cdot 50) \\
105 \cdot 72(10 \cdot 21) \\
40 \cdot 60(9 \cdot 27) \\
78 \cdot 70(7 \cdot 77)\end{array}$ & $\begin{array}{l}\text { NS } \\
\text { NS } \\
<0.02 \\
<0.05\end{array}$ \\
\hline
\end{tabular}

"Represents the percentage of counts per minute in experiments divided by counts per minute in $\mathrm{MC}+$ medium (the mean (SD) of controls is 8764 (878) counts per minute)

tCompared with the control, the $p$ values were assessed by the non-parametric Wilcoxon's signed rank test.

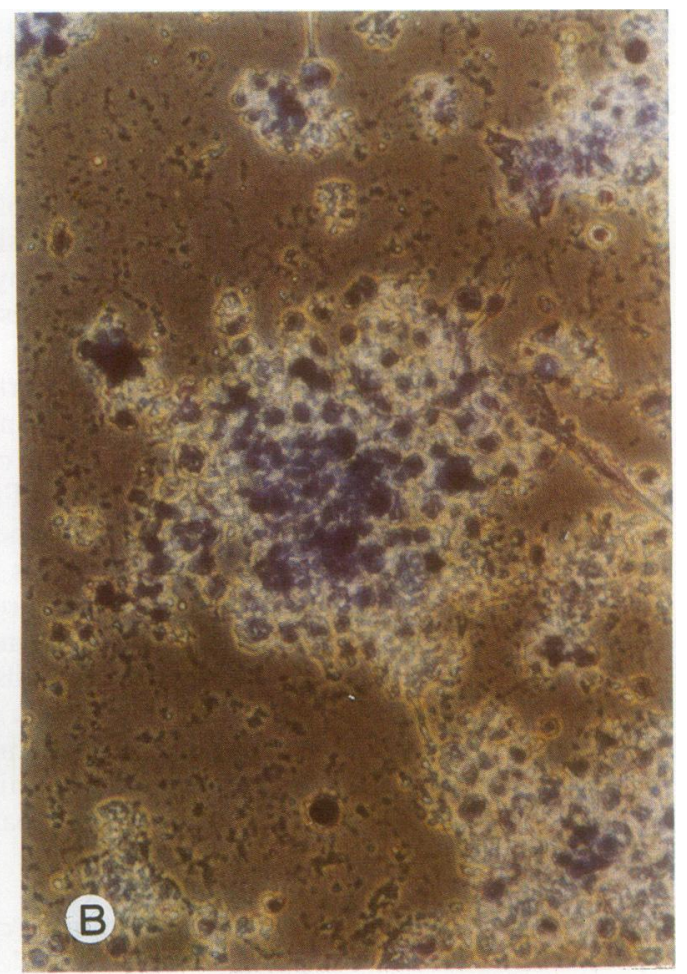

Figure 1 Morphological changes of cultured rat mesangial cells after incubation with $(A)$ medium or $(B) 100 \mathrm{IU} / \mathrm{ml}$ of antibodies to dsDNA for three days. The cells were fixed with $10 \%$ formalin at $37^{\circ} \mathrm{C}$ for 10 minutes followed by Wright's stain. The stellate mesangial cells became spherical and clustered together after incubation with antibodies to dsDNA $(B)$ 
Table 2 Effect of $f M L P\left(1 \times 10^{-7}\right.$ moll $)$, phorbol myristate acetate $(P M A)(10 \mathrm{ng} / \mathrm{ml})$, tumour necrosis factor $\alpha$ $(T N F-\alpha)(16 \mathrm{U} / \mathrm{ml})$, lipopolysaccharides $(L P S)(1 \mu \mathrm{g} / \mathrm{ml})$, interleukin $1 \beta(I L-1 \beta)(10 \mathrm{U} / \mathrm{ml})$ and $20 \%$ phytohaemagglutinin stimulated mononuclear cell supernatant (PHA-Sup.) on the ${ }^{3} \mathrm{H}$-thymidine incorporation of rat mesangial cells $\left(3 \times 10^{4}\right.$ cells per well) after three days of culture

\begin{tabular}{|c|c|c|c|c|c|c|}
\hline \multirow{2}{*}{$\begin{array}{l}\text { Experiment } \\
\text { No }\end{array}$} & \multicolumn{6}{|c|}{ Percentage of control ${ }^{*}$} \\
\hline & $f M L P$ & $P M A$ & $T N F-\varkappa$ & $L P S$ & PHA-Sup. & $I L-I \beta$ \\
\hline $\begin{array}{l}1 \\
2 \\
3\end{array}$ & $\begin{array}{l}104 \cdot 7 \\
113 \cdot 4 \\
106 \cdot 8\end{array}$ & $\begin{array}{l}102 \cdot 0 \\
100 \cdot 3 \\
113 \cdot 5\end{array}$ & $\begin{array}{l}107 \cdot 9 \\
126 \cdot 5 \\
104 \cdot 7\end{array}$ & $\begin{array}{l}87 \cdot 2 \\
70 \cdot 9 \\
91 \cdot 5\end{array}$ & $\begin{array}{r}109 \cdot 4 \\
96.6 \\
107.6\end{array}$ & $\begin{array}{r}87 \cdot 0 \\
104.6 \\
98 \cdot 7\end{array}$ \\
\hline
\end{tabular}

*Represents the percentage of counts per minute in experiments divided by the counts per minute in control wells (mean (SD) is 6540 (557) counts per minute).

spherical and clustered together with negligible evidence of proliferation. The heat aggregated $\mathrm{IgG}$ at a final concentration of $1 \mathrm{mg} / \mathrm{ml}$ exerted a non-significant effect on the perecentage of proliferation $(105 \cdot 72(10 \cdot 21) \%)$ compared with normal human IgG (table 1). Anticardiolipin antibodies $(90 \mu \mathrm{g} / \mathrm{ml})$, characteristic autoantibodies commonly found in patients with SLE, also exerted inhibition $(78 \cdot 70(7 \cdot 77) \%$ of the control) on the proliferation of mesangial cells (table 1), but with less effect.

Table 3 Effect of antibodies to dsDNA $(100 \mathrm{IU} / \mathrm{ml})$ on the production of prostaglandin $E$ $(P G E 2)$, prostacyclin (6-keto-PGF $\left.F_{14}\right)$, and thromboxane $B_{2}(T X B 2)$ in the supernatant of epidermal growth factor $(E G F, 6.5 \mathrm{ng} / \mathrm{ml})$ stimulated rat mesangial cells $\left(3 \times 10^{+}\right.$cells per well) after three days of culture

\begin{tabular}{|c|c|c|c|}
\hline & \multicolumn{3}{|c|}{ Concentration $(\mathrm{ng} / \mathrm{ml})$} \\
\hline & $P G E 2$ & 6-keto-P $P G F_{l}$ & $T X B 2$ \\
\hline $\begin{array}{l}\mathrm{MC}+\mathrm{EGF} \\
M C+E G F+I g G(1 \mathrm{mg} / \mathrm{ml}) \\
M C+E G F+\text { anti-dsDNA } \\
\text { p Value* }\end{array}$ & $\begin{array}{l}27 \cdot 88(5 \cdot 41) \\
24 \cdot 13(6 \cdot 51) \\
7 \cdot 39(2 \cdot 41) \\
<0 \cdot 005\end{array}$ & $\begin{array}{l}7.47(2.15) \\
8.15(3.08) \\
2.34(0.96) \\
<0.005\end{array}$ & $\begin{array}{l}0.62(0.15) \\
0.56(0.20) \\
0.17(0.06) \\
<0.005\end{array}$ \\
\hline
\end{tabular}

${ }^{*}$ Comparison between MC+EGF+anti-dsDNA and MC+EGF+IgG; the $p$ values were assessed by non-parametric Wilcoxon's signed rank test.

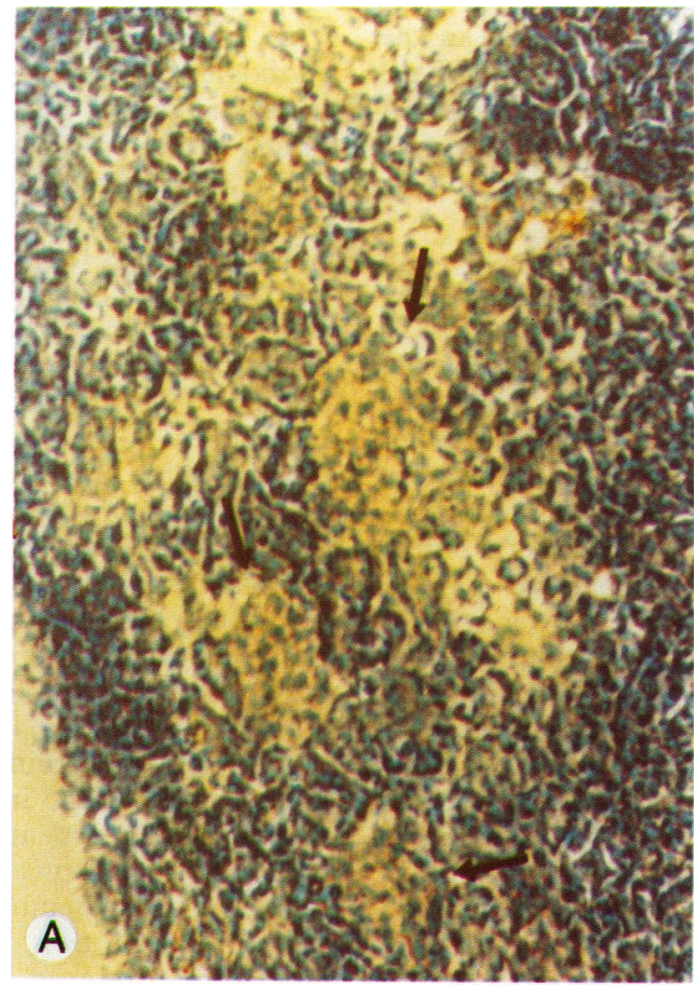

EFFECTS OF VARIOUS BIOLOGICALLY ACTIVE REAGENTS ON THE GROWTH OF MESANGIAL CELLS Table 2, shows that fMLP $\left(1 \times 10^{-7} \mathrm{~mol} / \mathrm{l}\right)$, PMA (10 ng/ml), tumour necrosis factor $\alpha$ (16 $\mathrm{U} / \mathrm{ml}$ ), lipopolysaccharides ( $1 \mu \mathrm{g} / \mathrm{ml}$ ), interleukin $1 \beta(10 \mathrm{U} / \mathrm{ml})$ and $20 \%(\mathrm{v} / \mathrm{v})$ phytohaemagglutinin (PHA) stimulated mononuclear cell culture supernatant did not affect the growth of mesangial cells.

EFFECTS OF ANTIBODIES TO dsDNA ON THE EICOSANOID METABOLISM

Epidermal growth factor $(6.5 \mathrm{ng} / \mathrm{ml})$ can stimulate mesangial cells to synthesise the arachidonic acid metabolites. Table 3 shows that the antibodies to dsDNA (100 IU/ml) greatly decreased the production of prostaglandin $\mathrm{E}_{2}$, 6-keto-prostaglandin $\mathrm{F}_{1 \mu,}$, and thromboxane $B_{2}$ by epidermal growth factor stimulated mesangial cells in three days of culture.

GLOMERULOTROPIC CHARACTERISTIC OF THE ANTIBODIES TO dsDNA IN VIVO

The immunoperoxidase stain of the renal sections (fig 2) showed a strong yellowish brown

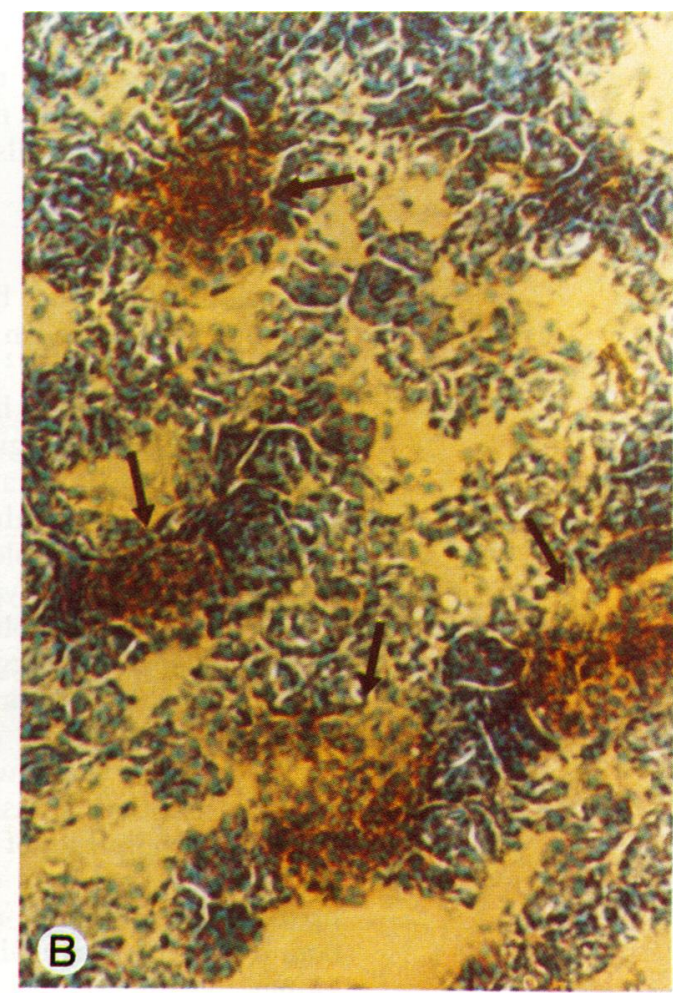

Figure 2 Immunoperoxidase stain of the frozen sections of kidneys from rats six hours after the intravenous infusion of (A) $4 \mathrm{mg}$ per $0.8 \mathrm{ml}$ normal human IgG or $(B) 320 \mathrm{IU}$ per $0.8 \mathrm{ml}$ of antibodies to dsDNA. The sections were counter stained with Meyer's haematoxylin. A yellowish brown tinge is noted in the glomerular mesangium in panel $B$. 


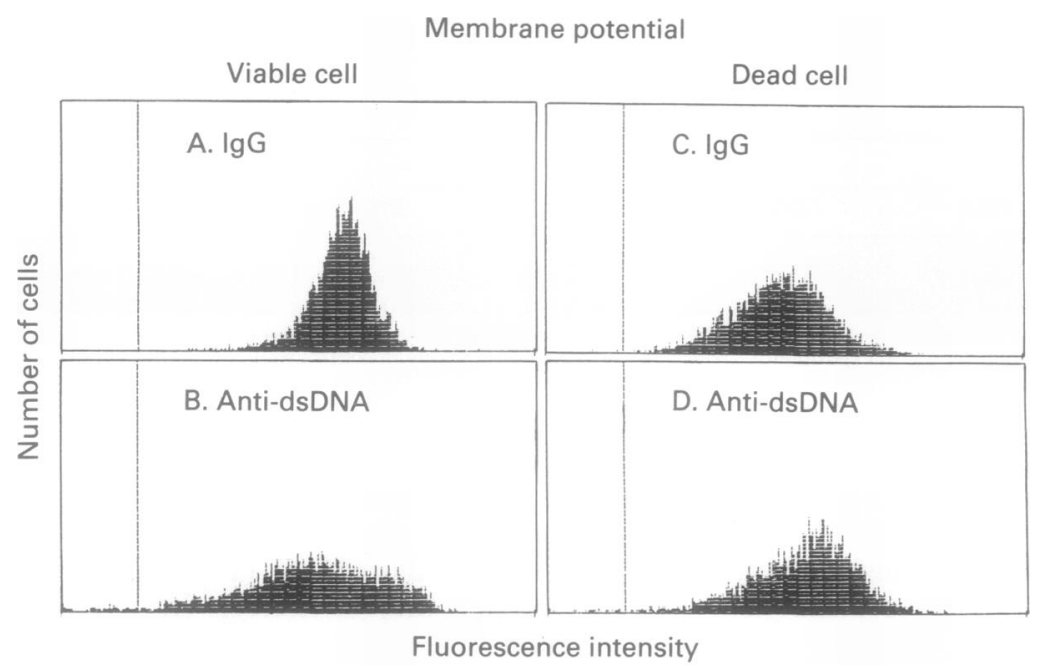

Figure 3 Typical example of membrane potential changes of mesangial cells after incubation with $1 \mathrm{mg} / \mathrm{ml}$ human IgG $(A$ and $C)$ or $100 \mathrm{IU} / \mathrm{ml}$ antibodies to dsDNA ( $B$ and $D$ ) for three days. After incubation, the dead cells floating in the medium were aspirated and the viable cells were harvested by $0 \cdot 125 \%$ trypsin. The membrane potential of viable $(A$ and $B$ ) and dead $(C$ and $D)$ mesangial cells were measured separately by flow cytometry using 3,3'-dihexyloxacarbocyanine as the probe. Depolarisation was noted in viable cells after incubation with antibodies to dsDNA. colour confined to the glomeruli rather than the tubular interstitium in the rats injected with antibodies.

EFFECT OF ANTIBODIES TO dsDNA ON THE MEMBRANE POTENTIALS OF THE CULTURED MESANGIAL CELLS

To determine if the antibodies to dsDNA interact with the plasma membrane of the mesangial cells, the membrane potentials of the mesangial cells before and after incubating with antibodies were evaluated by flow cytometry. Depolarisation of the cell membrane of the viable mesangial cells (those attached to the bottom of the sample flask) was noted in the presence of antibodies to dsDNA (100 IU/ml) for three days, whereas no distinct change could be seen in the dead cells (fig 3 ).

\section{Discussion}

Cellular immunity has been recognised to play an important part in the pathogenesis of glomerulonephritis. ${ }^{21} 22$ Investigations using monoclonal antibodies have shown that hypercellularity of the mesangium in active glomerulonephritis is due to infiltrating immune competent cells rather than to the proliferation of the mesangial cells. ${ }^{23}$ Pathologically, lupus nephritis is regarded as a prototype of immune complex mediated glomerulonephritis. However, there is much evidence to suggest that antibodies to dsDNA may cross react with proteoglycan, ${ }^{12}$ cell surface proteins, ${ }^{13}$ cytoskeletal proteins, ${ }^{14}$ and even living mononuclear cells. ${ }^{16} 24$ Izui $e t$ $a l^{25}$ reported that it was very difficult to detect circulating complexes of DNA and antibodies to DNA in patients with active SLE. Raz et al further showed that antibodies to dsDNA bound directly to renal antigens and induced kidney dysfunction in isolated rat kidneys.

In this study, we purified antibodies to dsDNA from pooled serum samples of patients with active SLE using a lambda phage dsDNA affinity column and found that these autoantibodies exert profound inhibitory effects on rat mesangial cells. These antibodies caused conspicuous morphological changes, growth inhibition, and decreased production of arachidonic acid metabolites by mesangial cells. Mesangial cells play an important part in regulating renal haemodynamics, controlling the macromolecule filtration, and secreting matrix substances. ${ }^{26} 27$

In the light of this information, it is conceivable that mesangial cells are more likely to be stationary cells for maintaining the integrity of the glomeruli rather than migratory phagocytic cells with destructive capacity. Our finding of cytotoxic effects exerted by antibodies to dsDNA on mesangial cells is significant and has not been reported previously. The damage of the glomerular mesangial cells may lead to multiple deleterious effects to the glomerular functions: ( $a$ ) decreased clearance of circulating immune complexes by the kidney; $(b)$ loss of haemodynamic regulation by the mesangium; and $(c)$ imbalance between vasodilative and vasoconstrictive arachidonic acid metabolites in the kidney. These abnormalities may accelerate glomerulosclerosis in lupus nephritis. It can then be reasonably inferred that in addition to the formation of complexes between DNA and antibodies to DNA, the antibodies to dsDNA may impair the glomerular functions partly by direct attack on mesangial cells.

The other autoantibodies capable of causing renal damage in patients with SLE were discussed by Wilkowski et al. ${ }^{28}$ They described glomerulonephritis in a patient with SLE in the presence of anticardiolipin antibodies. Our results showed a similar but less prominent effect of partially purified anticardiolipin antibodies on the growth of mesangial cells. This inhibitory activity of anticardiolipin antibodies is possibly present as the antibodies may bind to the negatively charged phosphodiester group on the surface membrane of the actively proliferating cells. ${ }^{17} 18$ In contrast, negligible effects of aggregated IgG, fMLP, tumour necrosis factor $\alpha$, interleukin $1 \beta$, lipopolysaccharides, PMA or PHA stimulated mononuclear cell supernatant on mesangial cell proliferation were found in this study. These results are inconsistent with previous reports. ${ }^{19} 29-32$ The reason for this is unclear. However, the differences in the age of the cultured mononuclear cell and the potency of the various reagents may be one of the causes for this inconsistency.

Another interesting observation is the glomerulotropic property of antibodies to dsDNA shown by infusing antibodies into normal rats in vivo. Whether the antibody binding sites are confined to the mesangial areas or are also present in the endothelium, epithelium, or basement membrane is hard to identify by light microscopy. For the exact localisation of the antibodies in the glomeruli, an immunoelectron microscopic study is necessary. However, it is certain that no deposition could be seen in the renal tubules or interstitium. This result is similar to that of $\mathrm{Raz}$ et al. ${ }^{9}$ 
In another experiment, we incubated purified antibodies to dsDNA with a frozen section from the kidney of a normal human subject and found that the antibodies bound to the glomeruli (data not shown). In a previous report, ${ }^{16}$ we showed that antibodies to dsDNA deranged the lymphocyte functions by cross reacting with the antigen(s) on the cell membrane. In this study, we further showed that antibodies to dsDNA depolarised the cell membrane of mesangial cells and deranged their function. It is conceivable that intervention of the membrane potential may transduce certain signals into the interior of the cells and inhibit the growth of mesangial cells.

To clarify further the mechanism of cytotoxic effects of these autoantibodies on mesangial cells, the determination of cytoplasmic $\left[\mathrm{Ca}^{2+}\right] \mathrm{i}$ and endonuclease activity, evaluation of DNA fragmentation, phosphatidyl inositol turnover, and protein kinase quantitation in mesangial cells after incubation with antibodies to dsDNA are necessary. Several of these are currently under investigation in this laboratory.

In conclusion, the glomerulotropic antibody to dsDNA is one of the nephrotoxic factors that can directly adversely affect the glomerular function in patients with SLE.

This work is supported by grants from the National Science Council and from the Institute of Biomedical Sciences, Academi Sinica, ROC. We are grateful to Miss Whu-Mei Lin and Miss Lina Lin for their technical assistance. We are also indebted to Miss Chun-Shia Chong for preparing the manuscript.

1 Hooke D H, Hancock W W, Gee D C, Kraft N, Atkins R C Monoclonal antibody analysis of glomerular hypercellularity in hum.

2 Magil A B, Wadsworth L D. Monocytes in human glomerulo nephritis-an electron microscopic study. Lab Invest 1981 45: 77-81.

3 Tipping P G, Neale T J, Holdsworth S R. T lymphocyte participation in antibody-induced experimental glomerulonephritis. Kidney Int 1985; 27: 530-7.

4 Holdsworth S R, Thomson N M, Glasgow E F, Dowling J P, Atkins R C. Tissue culture of isolated glomeruli in experimental crescentic glomerulonephritis. $\mathcal{f} E x p$ Med 1978; 147: 98-109.

5 Casals S P, Friou G J, Myers L L. Significance of antibody to DNA in systemic lupus erythematosus. Arthritis Rheum 1964; 7: 379-90.

6 Tan E M, Schur P H, Carr R I, Kunkel H G. Deoxyribonucleic acid (DNA) and antibodies to DNA in the serum of patients with systemic lupus erythematosus. $\mathcal{F}$ Clin Invest patients with systemic

7 Edberg J C, Tosic L, Taylor R P. Immune adherence and the processing of soluble complement-fixing antibody/DNA immune complexes in mice. Clin Immunol Immunopathol 1989; 51: 118-32.

8 Chetrit E B, Dunsky E H, Wollner S, Eilat D. In vivo clearance and tissue uptake of an anti-DNA monoclona antibody and its complexes with DNA. Clin Exp Immuno 1985; 60: 159-68.

9 Raz E, Brezis M, Rosenmann E, Eilat D. Anti-DNA antibodies bind directly to renal antigens and induce kidney dystunction in the isolated perfused rat kidney. $\mathcal{F}$ I mmunol 1989; 142: 3076-82.

10 Faaber P, Riike T P M, van de Putte L B A, Capel P J A, Berden J H M. Cross-reactivity of human and murine antiDNA antibodies with heparan sulfate. $\mathcal{F}$ Clin Invest 1986; 77: $1824-30$.

11 Chen X-M, Aozuka S, Kamata K, Okumura K, Kobayashi $Y$. Characterization of a polyreactive monoclonal antibody to dsDNA, FxIA, and heparan sulfate generated from BALB/c mice immunized with rat renal homogenates. Clin Immunol Immunopathol 1989; 51: 326-37.

12 Faaber P, Capel P J A, Rijke G P M, Vierwinden G, van de Putte L B A, Koene R A P. Cross-reactivity of anti-DNA antibodies with proteoglycans. Clin Exp Immunol 1984; 55: 502-8.

13 Jacob L, Tron F, Bach J-F, Louvard D. A monoclonal antiDNA antibody also binds to cell-surface protein(s). Proc Natl Acad Sci USA 1984; 81: 3843-5.

14 André-Schwartz J, Datta S K, Shoenfeld Y, Isenberg D A, Stollar B D, Schwartz R S. Binding of cytoskeletal proteins by monoclonal anti-DNA lupus autoantibodies. Clin by monoclonal anti-DNA lupus auto

15 Gilliam A C, Lang D, LoSpalluto J J. Antibodies to doublestranded DNA: purification and characterization of stranded DNA: purification and characterization
binding specificities. $\mathcal{F}$ Immunol 1980; 125: 874-85.

16 Yu C-L, Chang K-L, Chiu C-C, Chiang B N, Han S-H, Wang S-R. Alteration of mitogenic responses of mononuclear cells by anti-ds DNA antibodies resembling immune disorders in patients with systemic lupus erythematosus. Scand $\mathcal{f}$ R heumatol 1989; 18: 265-76.

17 Harris E N, Gharavi A E, Tincani A, et al. Affinity purified anti-cardiolipin and anti-DNA antibodies. $\mathcal{F}$ Clin Lab Immunol 1985; 17: 155-62.

18 Yu C-L, Sun K-H, Tsai C-Y, Wang S-R. Inhibitory effects of anticardiolipin antibodies on lymphocyte proliferation and
neutrophil phagocytosis. Ann Rheum Dis 1991; 50: 903-8.

19 Striker G E, Striker L J. Glomerular cell culture. Lab Invest 1985; 53: 122-31.

20 Shapiro H M, Natale P J, Kamentsky L A. Estimation of membrane potentials of individual lymphocytes by flow cytometry. Proc Natl Acad Sci USA 1979; 76: 5728-30.

21 Bhan A K, Schneeberger E E, Collins A B, McCluskey R T. Evidence for a pathogenic role of a cell-mediated immune mechanism in experimental glomerulonephritis. $\mathcal{f}$ Exp Med 1978; 148: 246-60.

22 Striker G E, Mannik M, Tung M Y. Role of marrow-derived monocytes and mesangial cells in removal of immune complexes from renal glomeruli. $\mathcal{f}$ Exp Med 1979; 149: 127-36.

23 Rees A J. Proliferation of glomerular cells. In: Catto G R D, ed. New clinical applications-nephrology-glomerulone phritis. Dordrecht: Kluwer Academic, 1990: 163-93.

24 Okudaira K, Yoshizawa H, Williams Jr R C. Monoclonal murine anti-DNA antibody interacts with living monomurine anti-DNA antibody interacts with living

25 Izui S. Lambert $\mathbf{P}$ H, Miescher $\mathbf{P}$ A. Failure to detect circulating DNA-anti-DNA complexes by four radioimmunological methods in patients with systemic lupus erythematosus. Clin Exp Immunol 1977; 30: 384-92.

26 Kriz $W \mathbf{K}$, Elger $M$, Lemley $K$, Sakai T. Structure of the glomerular mesangium: a biomechanical interpretation. Kidney Int 1990; 38 (suppl 30): S2-9.

27 Melcion C, Lachman L, Killen P D, Morel-Maroger L, Striker G E. Mesangial cells, effect of monocyte products on proliferation and matrix synthesis. Transplant Proc 1982; 14: $559-64$

28 Wilkowski M, Arroyo R, McCabe K. Glomerulonephritis in a patient with anticardiolipin antibody. Am $\mathcal{J}$ Kidney Dis 1990; 15: $184-6$.

29 Lovett D H, Ryan J L, Sterzel R B. Stimulation of rat mesangial cell proliferation by macrophage interleukin 1 . mesangial cell proliferation by

30 Pirotzky E, Delattre R M, Hellegouarch A, et al. Interleukin6 production by tumor necrosis factor and lipopolysaccharide-stimulated rat renal cells. Clin Immunol Immunopathol 1990; 56: 271-9.

31 Martin J, Lovett D H, Gemsa D, Sterzel R B, Davies M. Enhancement of glomerular mesangial cell neutral proteinase secretion by macrophages: role of interleukin 1. f I mmunol 1986; 137: 525-9.

32 Wiggins R C, Njoku N, Sedor J R. Tissue factor production by cultured rat mesangial cells. Stimulation by TNF- $\alpha$ and lipopolysaccharide. Kidney Int 1990; 37: 1281-5. 